Jurnal Widya Laksana, Vol.11, No.1, Januari 2022

\title{
PKM PEMANFAATAN LIMBAH TANAMAN PANDAN WANGI DI DESA CEPAKA, KEDIRI, TABANAN
}

\author{
Anak Agung Ayu Putri Permatasari ${ }^{1}$, Ni Kadek Yunita Sari ${ }^{2}$, I Made Endra \\ Puniawan $^{3}$
} ${ }^{1,2}$ Fakultas Kesehatan, Sains dan Teknologi Universitas Dhyana Pura, ${ }^{3}$ Fakultas
Ekonomi Bisnis dan Humaniora Universitas Dhyana Pura

email: putripermatasari@undhirabali.ac.id

\begin{abstract}
Abstrak
Tanaman pandan wangi tumbuh subur di negara beriklim tropis, yang biasanya dimanfaatkan sebagai campuran bahan masakan untuk membuatnya wangi dan enak. Daun pandan wangi mengandung zat alkaloida, polifenol, flavonoida, tannin, saponin dan juga zat warna alami. Senyawa tersebut dapat berperan sebagai anti bakteri, mengontrol kadar gula darah, mencegah kanker, mengatasi masalah gigi dan gusi, mengatasi kram, mengurangi rambut rontok dan masalah sakit kepala. Salah satu perkebunan pandan wangi yang terdapat di Bali yaitu UD. Melonila, yang terletak di Jalan Raya Munggu Desa Cepaka, Tabanan Bali. Hasil perkebunan pandan wangi biasanya dipasarkan ke pasar tradisional. Setelah dipanen tanaman ini harus segera didistribusikan agar tetap segar. Sedangkan tanaman yang merupakan sisa hasil panen memiliki kualitas yang hampir sama, tumbuh dengan cepat akan tetapi tidak mudah untuk dipasarkan. Oleh karena itu banyaknya hasil panen dari tanaman pandan wangi ini yang selalu tumbuh dengan cepat dan mudah menjadi permasalahan yang dialami oleh mitra, sehingga mitra ingin berinovasi mengembangkan produk dari limbah tanaman pandan menjadi desinfektan alami. Adapun metode pelaksanaan kegiatan yang dilakukan yaitu sosialisasi, pendampingan dan pelatihan pembuatan produk, menentukan kemasan dan merk dagang serta sisitem pemasaran melalui media sosial. Berdasarkan hasil PKM didapatkan bahwa kelompok tani pada UD. Melonila mengalami rata-rata skor peningkatan pengetahuan dan ketrampilan mengenai pemanfaatan limbah pandan wangi sebesar $83 \%$.
\end{abstract}

Kata Kunci: Desa Cepaka, desinfektan alami, inovasi, pemasaran

\begin{abstract}
Fragrant pandanus plants thrive in tropical countries, which are usually used to a mixture of cooking ingredients to make it fragrant and delicious. Fragrant pandan leaves contain alkaloids, polyphenols, flavonoids, tannins, saponins and also natural dyes. These compounds can act as anti-bacterial, control blood sugar levels, prevent cancer, overcome teeth and gum problems, treat cramps, reduce hair loss and headache problems. One of the fragrant pandanus plantations in Bali is UD. Melonila, which is located on Jalan Raya Munggu Cepaka Village, Tabanan Bali. Fragrant pandanus plantation products are usually marketed to traditional markets. Once harvested these plants must be distributed immediately
\end{abstract}


to keep them fresh. Meanwhile, plants which are the residue of the harvest have almost the same quality, grow quickly but are not easy to market. Therefore, the large number of harvests from this fragrant pandanus plant which always grows quickly and easily is a problem experienced by partners, so partners want to innovate to develop products from basil plant waste to become natural disinfectants. Therefore, product development is carried out by determining the trademark and packaging design as well as product marketing through social media. Based on the results of the PKM, it was found that the farmer groups experienced an average increase in knowledge about the utilization of fragrant pandanus waste by $83 \%$.

Keywords: Cepaka Village, natural disinfectant, innovation, marketing

\section{PENDAHULUAN}

Tanaman pandan wangi merupakan tanaman yang tumbuh dengan subur di negara beriklim tropis, daunnya dimanfaatkan sebagai bahan tambahan dalam masakan seperti menambah aroma maupun warna alami pada makanan. Meski demikian, tanaman ini juga dapat dimanfaatkan sebagai obat tradisional. Berdasarkan hasil dari penelitian Dewanti (2017) bahwa daun pandan wangi (Pandanus amayllifolius Roxb.) memiliki beberapa aktivitas farmakologi karena mengandung berbagai golongan senyawa yaitu flavonoid, alkaloid, saponin, tanin, polifenol yang memiliki peran dalam aktivitas farmakologinya. Aktivitas tersebut diantaranya yaitu antibakteri, antidiabetik, antikanker, dan antioksidan

Salah satu usaha atau budidaya pandan wangi ini terletak di Desa Kediri Kabupaten Tabanan. Usaha Dagang ini digagas oleh Arie Sutrisno dan diresmikan pada tanggal 17 Agustus 2019. Berdasarkan hasil wawancara dengan bapak Sutrisno, sebagai pemilik kebun bahwa luas perkebunan UD. Melonila sekitar 15 hektar terdiri dari perkebunan pandan wangi dan dikelola dalam usaha dagang yaitu UD.Melonila, yang terletak di Jalan Raya Munggu Desa Cepaka 14 petak dan 60 bedengan. Perkebunan ini secara eksklusif menawarkan produk daun pandan wangi segar, di mana perkebunan ini memiliki kapasitas produksi 30 kilogram daun pandan wangi yang segar setiap hari. Hasil perkebunan biasanya dipasarkan ke pasar tradisional.

Tanaman daun pandan wangi yang dipasarkan adalah tanaman yang sudah siap panen kurang lebih 1,5-2 bulan setelah ditanam. Setelah dipanen tanaman ini harus segera didistribusikan agar tetap segar. Sedangkan tanaman yang merupakan sisa hasil panen tidak mungkin dipasarkan, karena kualitasnya sedikit berkurang, sehingga permasalahan tersebut terus dialami oleh mitra, sehingga mitra ingin berinovasi mengembangkan produk dari limbah tanaman daun pandan wangi. Sehingga tujuan dari Tim PKM adalah melakukan pendampingan terhadap kelompok petani daun pandan wangi di Desa Cepaka untuk membuat inovasi produk yaitu desinfektan alami dari limbah daun pandan wangi. 


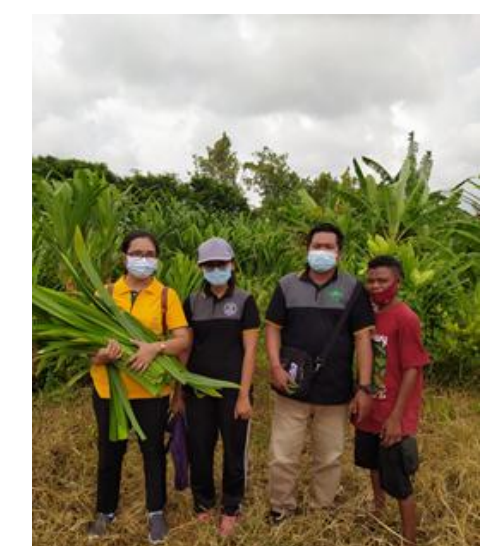

Gambar 1. Kebun Pandan Wangi Di Desa Cepaka, Kediri, Tabanan.

\section{METODE}

Mitra dari kegiatan ini kelompok petani pandan wangi di desa Cepaka. Kelompok terdiri dari 5 orang. Untuk mengukur keberhasilan PKM pada mitra, terdapat dua indikator tujuan terukur dalam jangka panjang yaitu: mitra memiliki keterampilan dalam membuat desinfektan, memiliki merk dagang serta kemasan produk dan memiliki strategi pemasaran produk.

Kegiatan ini dilaksanakan dengan memberikan pelatihan dan pendampingan metode membuat desinfektan alami daun pandan wangi. Proses pembuatannya diawali dengan persiapan alat dan bahan, penentuan dosis penambahan chlor ke dalam larutan pandan wangi. Pengambilan bahan dilakukan oleh petani dan mahasiswa, kemudian daun kita bersihkan terlebih dahulu dan kita keringanginkan. Setelah kering kita potong kecil kecil agar mudah diproses. Setelah itu rebus akuades/air dan masukkan daun pandan. Dinginkan rebusan daun pandan, kemudian kita tambahkan chlor dan aduk agar larutan tercampur merata. Setelah itu baru kita kemas ke dalam botol jerigen sesuai volume yang diinginkan, dan diberikan label. Mengenai pelatihan ketrampilan membuat desinfektan diukur dengan memberikan pre-tes sebelum pendampingan dan pos-tes setelah pendampingan.

Pengemasan produk dan penggunaan merek dagang sangat membantu dalam mengkomunikasikan serta mudah diingat oleh konsumen sehingga produk memiliki nilai jual dipasaran. Tim PKM akan mendampingi mitra dalam melakukan pengemasan, menentukan dan merancang desain logo yang sesuai untuk produk desinfektan.

Dalam mengembangkan usaha mitra perlu adanya strategi pemasaran agar produk desinfektan mampu dipasarkan secara online. Pendampingan dan pelatihan yang akan diberikan berupa pendampingan pembuatan akun media sosial

Komponen yang di evaluasi dalam kegiatan pendampingan PKM kelompok petani pandan wangi di Desa Cepaka adalah sebagai berikut :

Aspek Produksi, yaitu tingkat pemahaman mitra dalam mengembangkan inovasi pengolahan tanaman pandan wangi menjadi produk desinfektan; aspek keterampilan yaitu tingkat keterampilan mitra dalam membuat desinfektan dan melakukan pengemasan dan aspek pemasaran yaitu tingkat kepuasan mitra terhadap strategi pemasaran yang ditentukan bersama dengan mitra dan tim PKM dan respon mitra, distributor, maupun pelanggan terhadap merek dagang dan kemasan yang telah ditentukan 


\section{HASIL DAN PEMBAHASAN}

PKM Pemanfaatan Limbah

Tanaman Panda Wangi Di Desa

Cepaka, Kediri, Tabanan Bali berlangsung mulai Bulan Mei hingga Bulan Desember 2020. Adapun hasil kegiatan yang dicapai yaitu adanya peningkatan pengetahuan dan ketrampilan mitra dalam memahami pemanfaatan bahan alam dalam hal ini daun pandan wangi sebagai produk inovasi yaitu desinfektan alami pandan wangi yang diukur dengan memberikan pre-tes sebelum pendampingan dan pos-tes setelah pendampingan. Adapun hasil pre-tes dan pos-tes yang diperoleh dari kelompok tani adalah sebagai berikut:

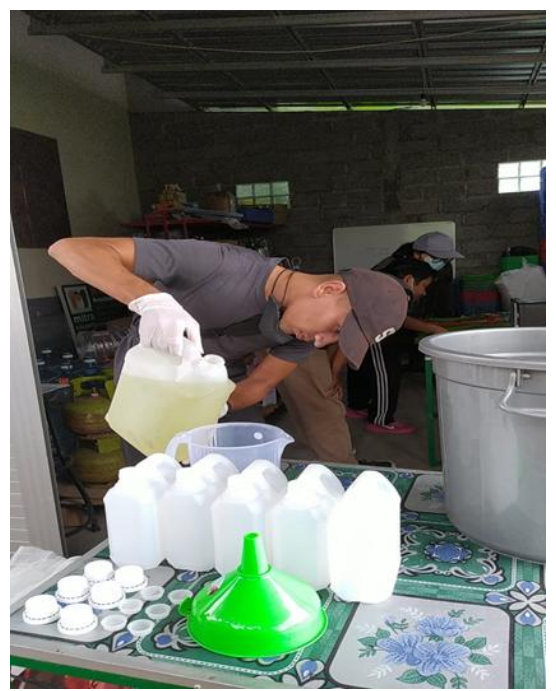

Gambar.2 .Proses Pembuatan Desinfektan

Tabel 1. Rata rata hasil pre-tes dan pos-tes

\begin{tabular}{lcc}
\hline Jumlah Kelompok & & \\
Tani & Pre-tes & Post-tes \\
\hline 5 orang & 60 & 83 \\
\hline
\end{tabular}

$\begin{array}{ccc}\text { Hasil } & \begin{array}{c}\text { tersebut } \\ \text { bahwa }\end{array} & \text { menunjukkan } \\ \text { sosialisasi, } & \text { pelatihan }\end{array}$ ketrampilan dan pendampingan tentang pembuatan produk desinfektan alami mampu memberikan pemahaman kepada petani UD. Melonila di Desa Cepaka, Kediri Tabanan sehingga dihasilkan produk desinfektan alami. Berdasarkan hasil pre-tes dan pos-tes dalam pengukuran peningkatan pengetahuan dan ketrampilan petani, diketahui bahwa terjadi peningkatan skor rata rata sebesar $83 \%$.

Kemudian produk desinfektan hasil pelatihan dan pendampingan dikemas dengan kemasan jerigen $1 \mathrm{~L}$ yang telah didesain khusus dengan merk dan logo dagang yang telah disepakati. Dengan adanya kemasan dan merk dagang ini diharapkan dapat meningkatkan harga jual produk desinfektan di pasaran. Adapun gambar produk desinfektan dengan kemasan dan brand produk sebagai berikut:

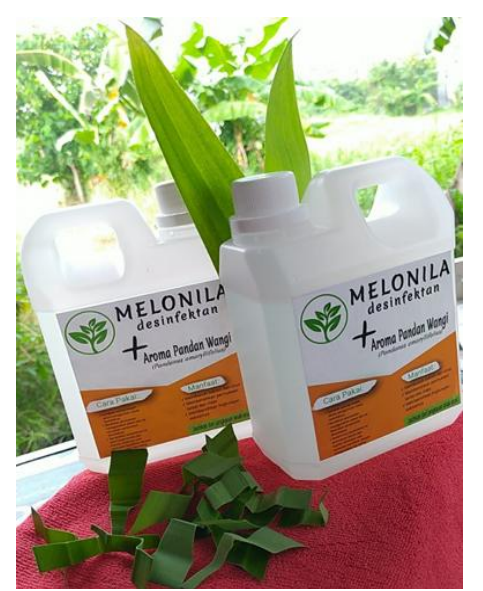

Gambar 3. Produk Desinfektan Dengan Kemasan dan Brand Produk 
Tim PKM berhasil melakukan pendampingan dan pelatihan untuk melakukan pemasaran produk secara online di sosial media yaitu melalui akun instagram.

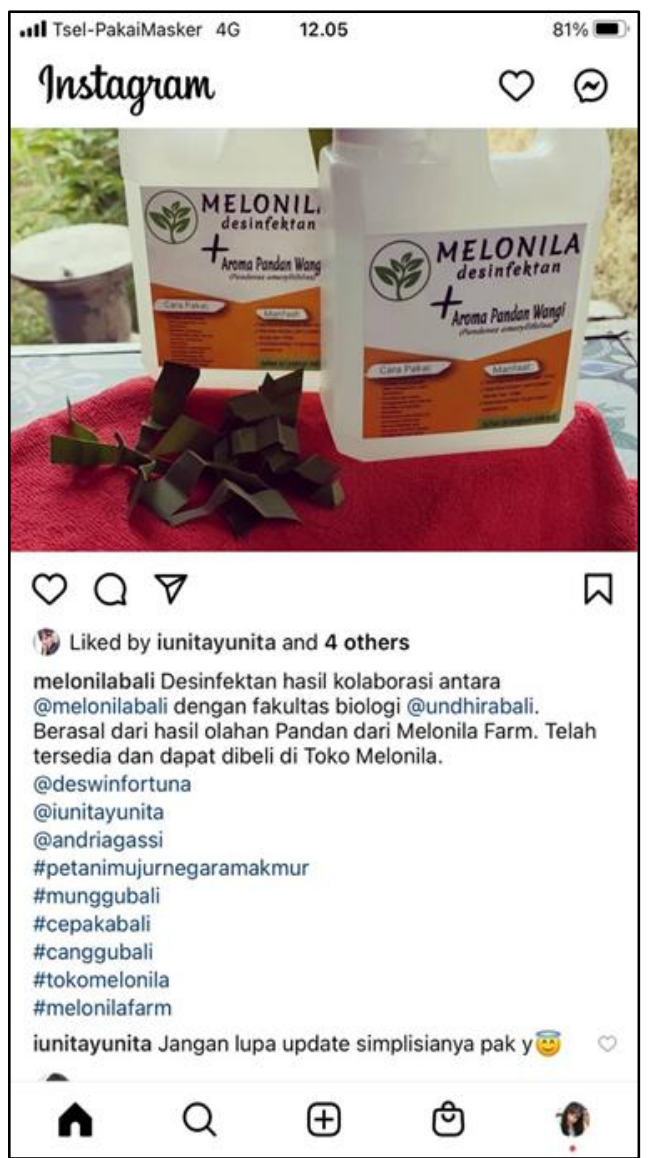

Gambar 4. Pemasaran produk desinfektan secara online

Untuk penjualan online belum terdapat penjualan karena baru beroperasi, tetapi kegiatan ini mampu menambah wawasan mitra bahwa penjualan bisa dilakukan secara online.

Evaluasi yang dilakukan pada kegiatan ini yaitu bermanfaat atau tidaknya kegiatan pendampingan ini. Berikut grafiknya dijabarkan pada Gambar 5.

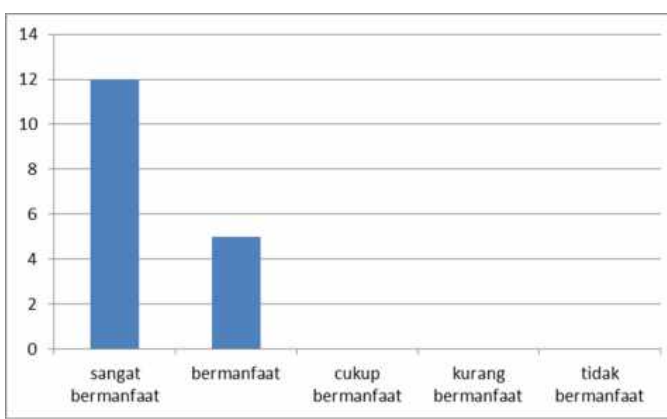

Gambar 5. Evaluasi dan pelatihan dalam pembuatan situs online dan teknik pemasaran

\section{KESIMPULAN}

Berdasarkan hasil kegiatan program kemitraan masyarakat di Desa Cepaka, Tabanan Bali dapat disimpulkan bahwa:

1. Mitra memiliki produk inovasi baru berupa desinfektan alami pandan wangi berupa produk desinfektan

2. Produk desinfektan memiliki merek dagang dan kemasan penjualan,

3. Mitra memiliki strategi pemasaran online melalui akun di instagram untuk penjualan produk

\section{DAFTAR PUSTAKA}

Dewanti, N,I.; Ferry, F.S.2017. Review Artikel: Aktivitas Farmakologi Ekstrak Daun Pandan Wangi (Pandanus amaryllifolius Roxb.). Jurnal Farmaka Suplemen. Volume 15. No.2.

Mellitus Lopez, D. C., and Nonato, M. G. 2005. Alkaloids from Pandanus amaryllifolius Coleected from Marikina, Philippines, Phillippine Journal 
Jurnal Widya Laksana, Vol.11, No.1, Januari 2022

Mardiyaningsih, dkk. 2014. Pengembangan Potensi Ekstrak Daun Pandan (Pandanus amaryllifolius Roxb) sebagai Agen Antibakteri. Pharmaçiana.4 (2): 185-192
Prameswari, O. M., dan Widjanarko, S. B. 2014. Uji Efek Ekstrak Air Daun Pandan Wangi Terhadap Penurunan Kadar Glukosa Darah Dan Histopatologi Tikus Diabetes. Jurnal Pangan dan Agroindustri 2(2) : 16-27 